\title{
A Questão Social Acrescida
}

\author{
The Increased Social Issue
}

\author{
Fernando G. Tenório ${ }^{1}$
}

\begin{abstract}
RESUMO
O objetivo do presente texto, ainda que de forma telegráfica ${ }^{2}$, é perguntar se o problema contemporâneo está resumido ao combate do coronavírus, cientificamente denominado de COVID-19, ou se outras carências não estariam desde sempre fazendo parte das patogenias inaladas e/ou enfrentadas pelos brasileiros. Aqui defendemos a posição de que tais patogenias orgânicas ou inorgânicas fazem parte de uma só, a questão social que no coetâneo foi acrescida do COVID-19.
\end{abstract}

Palavras chave: Questão econômica; questão sanitária; questão social.

\begin{abstract}
The purpose of this text, although in a telegraphic way, is to ask if the contemporary problem is limited to the struggle against the coronavirus, scientifically called COVID19 , or if other deficiencies would not always be part of the pathogens inhaled and / or faced by Brazilians. Here we defend the position that such organic or inorganic pathogens are part of one, the social question that in the contemporary world was added by COVID-19.
\end{abstract}

Keywords: Economic issue; health issue; social issue.

De acordo com o léxico da língua portuguesa, acrescer significa aumentar, adicionar ao já existente e no presente momento, à questão social soma-se o coronavírus, ou numa linguagem mais científica o COVID19. O tema dispensa explicações por ser contemporâneo, divulgado como uma pandemia sanitária massivamente transmitida pelas diferentes mídias, além de o presente texto pretender ser divulgado por meio de uma NAU preocupada com o social e não com o sanitário, ainda que este último adjetivo, por estar relacionado com a saúde pública, do social também trate. No entanto, aqui embarcaremos em uma nau que vai em busca da questão social que abarca, entre outras situações, a pandemia do coronavírus, a qual estamos submetidos. Desse modo, aqui entendemos que um tema sanitário - COVID-19 -, pertence, está inserido, na questão social e, como tal, também deve ser abordado.

Por sua vez, não devemos esquecer que o coronavírus, está sendo adicionado, cotidianamente, aos debates

\footnotetext{
1 Professor colaborador nas seguintes instituições de ensino superior (IES): EBAPE/FGV, UFSC, UFT e UNIJUÍ; professor visitante nas seguintes IES no Equador: UASB, EPN e UA; pesquisador visitante COPPE/UFRJ. E-mail: fernandoguilhermet@gmail.com. ${ }^{2}$ Talvez os não idosos não tenham tido a oportunidade de receber mensagens por meio dos telégrafos, apenas pela internet. Jovens,
o telégrafo, entre outros meios de comunicação, fez parte do avanço científico-tecnológico.
}

Artigo Convidado para compor este Fórum Especial em Democracia, Políticas Públicas e COVID-19. Agradecemos ao autor a participação neste debate tão urgente. 
da questão econômica. Para alguns, inclusive, a questão econômica está sendo subtraída, diminuída pelo coronavírus. Ou seja, nos debates sobre o coetâneo da economia, sublinhemos, a economia de mercado, a economia da "mão invisível", que está sendo ameaçada ou prejudicada por um agente infeccioso, não visível a olho nu, que não só afeta o organismo humano, a humanidade, mas causa prejuízo aos agentes econômicos, infectando-os, paralisando-os. Logo, não há como discutir a questão econômica sem relacionála à questão social, uma vez que a questão sanitária afeta a "higiene" da mão invisível, o mercado, como afeta de modo acentuado aquelas mãos, não mais no sentido metafórico, que não só dão vida ao mercado como o impulsionam por meio da venda da sua força de trabalho. Debater a questão econômica sem fazer relação com a questão social em meio a uma situação de pandemia sanitária não é "tapar o sol com a peneira", é fugir do debate.

Apesar de, pela dimensão do texto, ele não ser capaz de descrever a amplitude e o significado da questão social entendemos, dada a demanda da NAU Social, que a sua exposição na presente circunstância do COVID-19 tem importância, uma vez que o debate que o vírus provoca parece privilegiar a questão econômica em detrimento da questão social. Por questão econômica entenderemos todas aquelas decisões processadas segundo o entendimento de que o Estado deve intervir minimamente na economia, uma vez que os agentes econômicos, empresas privadas, devem agir em função de seus parciais interesses. Esse entendimento, ou no dizer de Karl Polanyi, "essa engenhoca institucional, (...) se tornou a força dominante da economia - agora justificadamente descrita como economia de mercado - originou um fenômeno ainda mais extremo: uma sociedade inteiramente inserida no mecanismo de sua própria economia - a sociedade de mercado" (POLANYI, 2012, p. 52, itálicos do autor). Ainda de acordo com Polanyi, essa engenhoca se transfez em um dogma religioso, um princípio indiscutível, do liberalismo econômico.

O liberalismo econômico foi o princípio organizador de uma sociedade engajada na criação de um sistema de mercado. Nascido como mera propensão em favor de métodos não burocráticos, ele evoluiu para uma fé verdadeira na salvação secular do homem através de um mercado autorregulável. Um tal fanatismo resultou do súbito agravamento da tarefa pela qual ele se responsabilizara: a magnitude dos sofrimentos a serem infligidos a pessoas inocentes, assim como o amplo alcance das mudanças entrelaçadas que a organização da nova ordem envolvia. O credo liberal só assumiu seu fervor evangélico em resposta às necessidades de uma economia de mercado plenamente desenvolvida (POLANYI, 2000, p. 166).

A questão social como tema de preocupação e estudo surge historicamente no século XIX, à luz das péssimas condições de trabalho originadas pela questão econômica. Desde então, a questão social deixa de ser um debate sobre as condições de trabalho para envolver outros temas, como educação, saúde, transporte, moradia, saneamento básico, segurança, lazer, cultura e segurança alimentar, assim como discussões sobre desigualdade de classe, gênero, raça/etnia, entre outros temas que afetem o bem-estar geral das populações menos favorecidas. Assim, entender a questão social seria entender essas disfunções por meio de políticas públicas, e não da esperança de que o sistema de mercado, ou simplesmente que a moral mercantil, seja solidário na solução dos problemas por ele mesmo gerados. Tentativas para a solução desses problemas foram planejadas principalmente com a concepção do Estado Providência, "que quase chegou a vencer a antiga insegurança social e a eliminar o medo do futuro [teve o seu fim iniciado a década de 1970 uma vez que] o crescimento do desemprego e o surgimento de novas formas de pobreza pareciam" (ROSANVALLON, 1998, p. 23) afastar-nos do ideal de um Estado provedor, do welfare state.

A questão social não está relacionada apenas aos temas acima mencionados, mas também a todo tipo de fobia, como a xenofobia - repulsa ao estrangeiro -, a homofobia - ódio aos homossexuais -, misoginia aversão a mulheres -, fobias religiosas - contra cristãos, judeus, mulçumanos e outras manifestações religiosas, por exemplo, aquelas de origem africana. Porém, segundo Adela Cortina (2017), há outra que está na raiz de muitas fobias, a aporofobia, patologia social que tem desprezo pelos pobres. Do grego á- 
poros, pobre, e fobéo, repelir, aporofobia "seria o ódio, repugnância ou hostilidade para com o pobre, o sem recursos, o desamparado" (CORTINA, 2017, p. 24). Manifestações aporofóbicas de vez em quando chegam a ser destaque na mídia, como veem-se em casos extremos de perseguições e até morte de mendigos, moradores de rua e imigrantes. E, no tempo do coronavírus, seja acrescentada a fobia aos idosos, idosofobia, que, segundo as estatísticas sanitárias, seria aquele estrato populacional mais propenso a ser afetado pelo COVID-19. Por ser mais perecível, uma vez que o seu prazo de validade para a economia de mercado não tem mais serventia, o idoso é descartável.

Nestes tempos de coronavírus incorporemos também outra variável à questão social relacionada às condições de trabalho: incorporemos a precarização do trabalho. Essa precarização, iniciada no começo da década de 1970, com o surgimento da flexibilização organizacional intensificada pelo crescimento vertiginoso da tecnologia da informação, vem promovendo de forma acelerada a automação da produção de bens e serviços. Associada a essa flexibilização organizacional surge a flexibilização do trabalho por meio não só da terceirização, mas também do desmonte da legislação trabalhista, fenômeno provocado, novamente, pelos ajustes na economia de mercado, um fato que não é exclusivamente brasileiro e tem origens e práticas em outras latitudes.

Acrescentemos a essas mudanças no mundo da produção, de bens ou serviços pelo menos dois neologismos nas condições de trabalho: a "uberização" e a "youtuberização". Em ambos os casos, principalmente com a uberização, mantém-se o trabalho escravo, surge um "new slave", já que sua maneira de trabalhar não é mais por meio da enxada, do facão e outros implementos manuais, mas mediante bicicletas, motocicletas e carros. O seu "ganha-pão" é por meio do delivery, nome que pretende sofisticar os atuais entregadores. Aliás, como os demais dependentes dos novos aplicativos empregatícios subiram de status, eles são "entrepreneurs".

Portanto, dado que os problemas sociais persistem aqui e alhures, quais políticas públicas poderão eliminar as variáveis que promovem a perene questão social, incluindo, agora, a questão sanitária, o COVID-19? Quem deve ser o fomentador para a solução desses problemas, a mão invisível ou a visível? O mercado ou o Estado? Claro que cabe ao Estado implementar políticas públicas minimizadoras ou eliminadoras das enfermidades sociais e/ou virais. Mas de qual Estado estamos falando? De um Estado provedor ou mínimo? Infelizmente, o que vem contagiando, desde os anos 1970, de forma intensa ou vigorosa tanto os países centrais como os periféricos é a ideologia, por que não o vírus, de uma modernização do aparelho do Estado, que passa, necessariamente, pela diminuição de atribuições desse aparelho, assim como pela diminuição de recursos destinados à questão social, com o argumento de que devemos implementar políticas fiscais que eliminem o déficit fiscal. Ou seja, as decisões estratégicas de governo, políticas fiscais, deixam de imunizar a sociedade contra os agentes patogênicos criados pelas contradições geradas pela economia de mercado, caso das condições de trabalho, como também pelas patogenias oriundas de vírus muitas vezes desconhecidos pelo sistema médico-sanitário. Desse modo, a busca pela eficiência fiscal pode resultar em mais deficiência social.

Recorrendo mais uma vez a Karl Polanyi, agora por meio da autora da introdução do seu estimulante livro A subsistência do homem e ensaios correlatos (2012), Michele Cangiani, quando diz que:

Na opinião de Polanyi, a eficiência social de qualquer organização - uma fábrica ou um partido, ou o sistema econômico como um todo [e por que não o Estado na sua particularidade] - é proporcional ao seu grau de 'democracia viva' (...). Na atualidade, temos de admitir que não apenas a democracia não se tornou 'substantiva', com uma participação generalizada, esclarecida e responsável dos cidadãos nas escolhas públicas, como até as instituições democráticas mais tendem a ser controladas, se não solapadas, pela pressão do poder empresarial e das lideranças populistas (POLANYI, 2012, p. 23-24).

Diante da contemporaneidade socioeconômica e político-institucional na qual vivemos no Brasil, tem-se de 
concreto a ocorrência de espasmos involuntários na solução do contágio pelo COVID-19. São espasmos na medida em que a burocracia pública do Estado brasileiro vem perdendo os seus antídotos, capacidade instalada e treinada, para implementar políticas públicas que deem conta do vírus orgânico e daquelas enfermidades sociais que vêm se agravando e que se agravaram de forma mórbida e/ou mortal com mais um coronavírus. E como combater simultaneamente enfermidades sociais e patogênicas? Políticas públicas são necessárias, e a sociedade deve mobilizar-se em defesa da coisa pública, isto é, do ensino público, da saúde pública, de estatais provedoras de insumos estratégicos para esta mesma sociedade, e ser também demandante de outras carências sociais para as quais o "deus mercado", por defender seus parciais interesses, não é útil, por mais enfermiças que sejam as necessidades.

Portanto, significa dizer que os diferentes agentes da sociedade constituem "múltiplos tipos de organização, mas também, e mais importante, que cada um deles pertence a enclaves distintos, no contexto da tessitura geral da sociedade" (GUERREIRO RAMOS, 1981, p. 134). Enquanto o agente público deve atuar objetivando a sociedade como um todo, de modo republicano, os agentes econômicos possuem "exigências próprias que não coincidem, necessariamente, com aquilo que é requerido pela qualidade da existência humana em geral" (IBIDEM, p. 135). Os agentes econômicos devem ser considerados "como pertencentes a um enclave conceptual e pragmaticamente limitado [mercado], dentro do espaço vital humano" (IBIDEM, p. 135), a sociedade. Portanto, a "organização econômica é apenas um caso particular de diversos tipos de sistemas microssociais, em que as funções econômicas são desempenhadas de acordo com diferentes escalas de prioridades [estratégias]" (IBIDEM, p. 135).

Concluindo, apesar das dificuldades presenciais por conta do COVID-19, a soberania popular por meio de processos dialógicos, ainda que virtuais, deve estar presente com o poder público, tanto para formular e acompanhar proposituras profiláticas como para exercitar o seu controle social. Para tanto é necessário que pratiquemos o patriotismo constitucional, uma vez que a nossa Carta Magna de 1988, ainda vigente, diz textualmente em seu Art. 10, "Parágrafo único. Todo o poder emana do povo, que o exerce por meio de representantes eleitos ou diretamente, nos termos desta Constituição" (BRASIL, 1988, p. 3). E é pelo direito de exercermos diretamente o nosso poder, como povo, que devemos estimular e praticar políticas públicas que promovam o bem-estar social e a saúde pública do Brasil. Os reclamos do lluminismo por liberdade, igualdade, solidariedade e justiça social só poderão ser alcançados se descolarmos democracia de capitalismo. Os dois substantivos não são combináveis, como até então é constatado por meio do crescente processo de desinstitucionalização brasileiro. Desinstitucionalização vai ao encontro da "noção de semicidadania [que] descreve as realidades plurais e diversas de vários grupos e indivíduos que vivem em democracias liberais hoje em dia, mas não têm acesso a todo o pacote de direitos de cidadania" (MAIA; PONTIN, 2019, p. 154) como desejaríamos. Portanto, esta semi ou quase cidadania não caracteriza a possibilidade de uma cidadania participante do processo de tomada de decisão no qual os diferentes atores sociais, oriundos do poder público, dos agentes econômicos (mercado) e das organizações da sociedade civil, dialoguem e deliberem, por meio de uma gestão compartilhada, dialógica, sobre os destinos da sociedade ou de interesses de seus enclaves.

\section{Referências}

ANDERSON, Perry. O fim da história: de Hegel a Fukuyama. Rio de Janeiro: Zahar, 1992.

BRASIL. Constituição (1988). Constituição: República Federativa do Brasil. Brasília: Senado Federal, Centro Gráfico, 1988.

CASTELLS, Manuel. Ruptura: a crise da democracia liberal. Rio de Janeiro: Zahar, 2018.

CORTINA, Adela. Aporofobia, el rechazo al pobre: un desafío para la democracia. Barcelona: Paidós, 2017. 
ENGELS, Friedrich. A situação da classe trabalhadora na Inglaterra. São Paulo: Boitempo, 2010.

GUERREIRO RAMOS, Alberto. A nova ciência das organizações: uma reconceituação da riqueza das nações. Rio de Janeiro: Editora FGV, 1981.

GIDDENS, Anthony. A terceira via: reflexões sobre o impasse político atual e o futuro da socialdemocracia. Rio de Janeiro: Record, 1999.

MAIA, Tatiana Vargas; PONTIN, Fabrício. Cidadania, semi-cidadania e democracia no Brasil contemporâneo. In: PINHEIRO-MACHADO, Rosana; FEIXO, Adriano de (Orgs.). Brasil em transe: bolsonarismo, nova direita e desdemocratização. Rio de Janeiro: Oficina Raquel, 2019. p. 144-160.

POLANYI, Karl. A grande transformação: as origens da nossa época. 2. ed. Rio de Janeiro: Campus, 2000.

A subsistência do homem e ensaios correlatos. Rio de Janeiro: Contraponto, 2012.

ROSANVALLON, Pierre. A nova questão social: repensando o Estado Providência. Brasília: Instituto Teotônio Vilela, 1998. 